\title{
Technical Efficiency of Sweet Potato Production: A Stochastic Frontier Analysis
}

\author{
Godfrey C. Onuwa $a^{1, a, *}$, Solomon T. Folorunsho ${ }^{2, b}$, Ganiyu Binuyo ${ }^{1, \mathrm{c}}$, \\ Mercy Emefiene ${ }^{3, d}$, Onyekwere P. Ifenkwe $e^{4, e}$ \\ ${ }^{1}$ Department of Agricultural Extension and Management, Federal College of Forestry, Jos, Plateau state, Nigeria \\ ${ }^{2}$ Department of Agricultural Economics, University of Jos, Plateau state, Nigeria \\ ${ }^{3}$ Department of Crop Production Technology, Federal College of Forestry, Jos, Plateau state, Nigeria \\ ${ }^{4}$ Department of Plant Science, University of Jos, Plateau state, Nigeria \\ *Corresponding author
}

A R T I C L I N F O A B S T R A C T

Research Article

The level of yield among sweet potato farmers is on a decline; low output and yield differences was observed, indicating the existence of inefficiency in production systems and variations in input utilization. Efficiency in resource use must be sustained in order to improve productivity and maximize farm output. This study therefore analyzed the technical efficiency of sweet potato

Received : 07/08/2020 Accepted : 31/05/2021 production. Multi-stage sampling techniques were adopted in selecting 94 respondents for this study. Data collected was analyzed using descriptive statistics and stochastic frontier production function. The socioeconomic variables of the respondents affected their farm efficiency and level of farm output. The estimated ratio of the L/R test was 0.579 ; indicating a goodness of fit of the frontier model and thus a rejection of the null hypothesis. The coefficients of sweet potato seeds (vines) (0.362) and labour (0.439) were positive and statistically significant at $5 \%$ level of probability, while the coefficients of farm size $(-1.333)$, fertilizer $(-0.452)$ and herbicides $(-0.766)$

Keywords: Constraints Efficiency index Farm output Production inefficiency Resource utilization were negative but statistically significant at $5 \%$ level of probability. The inefficiency model revealed that the coefficient of farm capital $(-0.172)$, education $(-2.281)$, access to credit $(-0.472)$, farming experience (-0.639), extension contact (-0.733) and membership of cooperatives (-0.396) were negative and statistically significant at $5 \%$ level of probability. The mean technical efficiency was $0.62(62 \%)$ implying that the sweet potato farmers in the study area were not producing at optimal capacity. The constraints identified significantly affected sweet potato production in the study area. Subsidizing input costs; sensitizing farmers on appropriate farming practices, cooperative formation and efficiency in resource utilization; improving access to agricultural inputs, technology, farm capital, credit and extension services, market linkages, farm labour supply and the development of indigenous technologies in sweet potato production are strongly recommended.

\begin{tabular}{|c|c|c|c|}
\hline $\begin{array}{l}\text { onuwag@gmail.com } \\
\text { abdulganiyu1972@gmail.com } \\
\text { bullion14@yahoo.com }\end{array}$ & $\begin{array}{l}\text { (D) https://orcid.org/0000-0001-5657-9427 } \\
\text { (iD) https://orcid.org/0000-0002-8435-517X } \\
\text { (iD) https://orcid.org/0000-0001-8785-9982 }\end{array}$ & $\begin{array}{l}\text { b@ solomon2012@gmail.com } \\
\text { d@ mercyfcf@gmail.com }\end{array}$ & $\begin{array}{l}\text { (iD) https://orcid.org/0000-0003-3952-9692 } \\
\text { (iD) https://orcid.org/0000-0001-7247-473X }\end{array}$ \\
\hline
\end{tabular}

(c) (1) () T) This work is licensed under Creative Commons Attribution 4.0 International License

\section{Introduction}

Sweet Potato (Ipomoea Batatas) is a root vegetable that produces tuberous roots (Huntington Lib., 2006). It is a tropical root crop, with more than 100 million tons produced globally per annum (Warammboi et al., 2011; UNCTAD, 2012; FAOSTAT, 2007). Propagation is by adventitious roots, stem, or root cuttings (Huntington Lib., 2006). China currently accounts for more than half of the total global sweet potato output at 55 million metric tons per annum. Nigeria is among the world's largest producers of sweet potato with an average of over 1 million metric tons produced annually (Huntington Lib., 2006), yet the average yield of 7 tons/ha in Nigeria were below the yield potential of about 35 tons/ha in China using similar labour intensive and technology (FAOSTAT, 2007). However, 15 tons per hectare is attainable by farmers in Nigeria using improved varieties (Okonkwo and Okoli, 2000). In a study carried out by Okonkwo and Okoli (2000) it was revealed that while irrigated irish potato production is an economically viable venture, it is more economically reasonable to cultivate (grow) sweet potato under rain fed condition in the study area: which implies that farmers here monopolize the agro-ecological environment in growing this crop during the rainy season. Despite the importance of sweet potato, it is considered a minor crop in terms of 
production and consumption in Nigeria (Adewumi and Adebayo, 2008; UNCTAD, 2012; Woolfe, 2002). In a study carried out by FAOSTAT (2007), it was reported that 115 countries produced 106,569,572 tons of Sweet potatoes in 2010. However, supply remains very concentrated; $82.3 \%$ of the global production being in Asia with $81,175,660$ tons, China produced by far the largest part and possesses a little less than half of the global acreage dedicated to the sweet potato. Indonesia is the second Asian producing country and the 4th in the world with more than 2 million metric tons of production, for example in the Papua province in Indonesia, 90\% of the dishes contain sweet potato. The second continent in the world of sweet potato production is Africa. Africa contributed up to $14 \%$ of the global production with more than 14.2 metric tons. Contrary to the main producing countries which have seen their production level decline over the years, some Africa countries have increased their production level from 2 metric ton in 1999 to 2.83 metric ton in 2010 (FAOSTAT, 2007). Nigeria and Tanzania produce $1.43 \mathrm{Mt}$ and $1.4 \mathrm{Mt}$ respectively (FAOSTAT, 2007). This expansion in Africa is linked to a strong demographic growth. However, Latin America which is the global sweet potato arena, produced $1.97 \mathrm{mt}$ in 2010 , that is, a little more than $2 \%$ of the global supplies. In a study carried out by FAOSTAT (2007) it was reported that Nigeria was ranked the second largest producer of sweet potato after Uganda in Africa. In a study carried out by UNCTAD (2012) it was reported that sweet potato production in terms of land size used from 2002 to 2012 depicts a law of diminishing returns. In this report, from 2003 to 2006, there were increased and moderate relationships between production per tones and land sizes used, but in 2007 there was a sharp decrease in production even though the land size was increased to about $10.8 \%$. This increase was the biggest in the whole decade while the 2008 gave a remarkable change. Production figure rose to about $36.4 \%$ and land size declined to about $2.2 \%$. But the periods 2009, 2010 and 2011 show that production and land size used remained unchanged with yields figures of 15000 tons/ha. Lastly, in 2012 the yield figure was increased to $1.6 \%$. The cultivation and utilization of sweet potato have not received appropriate attention of the Nigerian populace despite its nutritional constituents, ease of propagation, soil conservation attribute and industrial use (Woolfe, 2002). It was regarded as a crop with little economic importance. Its consumption was surrounded by the erroneous idea that it caused amoebic dysentery (Woolfe, 2002). The minimal utilization of sweet potato in Nigeria may also be attributable to non-availability of adequate sweet potato- based recipes that satisfy the food habits of Nigerians (Adewumi and Adebayo, 2008; Warammboi et al., 2011). Of the estimated 150 million tons of all root and tubers produced in Nigeria annually, sweet potato contributes only 13\% (Horton, 2008; Ekwelle et al., 2001). In Nigeria, the production, marketing and utilization of sweet potato have expanded to almost all the ecological zones within the past decade (Ekwelle et al., 2001; AduKwarteng et al., 2002; FAOSTAT, 2007). Sweet potato is the second highest source of energy crop after cassava producing $465 \mathrm{KJ}$, that is, only $125 \mathrm{KJ}$ less than cassava (SPU, 2013). Industrially, sweet potatoes flour can be used to substitute wheat flour in bread making or maize flour in balanced feeds. Energy is measured in kilocalories (Kcal), calories or Kilojoules $(\mathrm{KJ})$, and 1 kilocalorie $=4.2$ kilojoules). However, industrial potentials of sweet potato have not been exploited due mainly to a chronic lack of awareness about the numerous commercial benefits derived from it (Azogu and Olomo, 2002).

The analysis of efficiency is generally associated with the possibility of farms producing a certain optimal level of output from a given bundle of resources or a certain level of output at least cost (Amaza, 2007). Efficiency can be defined as the relative performance of the processes used in transforming input into output (Amaza, 2007). It could also be defined as the attainment of production goals without waste (Ajibefun et al., 2002).The pivotal role of efficiency in accelerating agricultural productivity and output has been applauded and investigated by numerous researchers within Africa and outside. The decreased output of food crop production over the years may not only be connected with deviations of farmers' practices from technical recommendations but also with the use of resources at sub-optimal levels which ultimately leads to technical and allocate inefficiencies (Coelli et al.,1998). An underlying premise behind much of the research inefficiency is that farmers are not making efficient use of existing technology, then efforts designed to improve efficiency would be more cost-effective than introducing new technologies as a means of increasing agricultural output (Adeleke et al., 2008). Broadly, two quantitative approaches are developed for measurement of production efficiency: Parametric (Stochastic frontier approach) and non-parametric (Data envelopment analysis) approaches. The data envelopment analysis (DEA) has no fixed functional form and does not account for noise in the data. Thus, all deviation from the frontier will be accounted for as inefficiencies (Amaza, 2007). The Stochastic frontier approach is parametric and is sensitive to the choice of functional form and accounts for random errors. In this approach all deviations from the frontier are due to random effects and inefficiency (Coelli et al, 2002). The stochastic frontier production was independently proposed by Aigner, et al. (1977) and Meeusen and Van den Broeck (1977). The measurement of efficiency is important because it leads to substantial resource savings. Early application of stochastic frontier production functions was first used in the analysis of the United States agricultural data. Battese and Corra (1977) applied the techniques to the pastoral zone of Eastern Australia. And more recently, empirical application of the techniques in efficiency analysis have been reported (Ojo and Ajibefun, 2000; Ojo, 2003; Dawang, 2006; Usman, 2009; Amaza, 2007). Several studies have identified numerous socioeconomic variables that influence efficiency of inputs use. These factors include age, education, farmer's experience, contact with extension agents, income of the farmers and access to credit. Awudu and Richard (2001) reported that efficiency increased with the age until a maximum efficiency was reached. Alene and Hassan (2003) reported that technical efficiency of Ethiopian farmers was positive and significantly influenced by education level, credit and contact with extension workers. Ugunyinka and Ajibefun (2003) observed that education and membership of Farm association were the most important factors affecting efficiency. Education level and farming experience have 
been reported to have a positive and significant impact on technical efficiency (Adewuyi and Okunmadewa 2001). Extension contact has been reported to have a positive and significant relationship with efficiency (Amaza, 2007). Therefore, farmers that have had extension contacts are likely to be more efficient than those without any extension contact. Greater family size increase efficiency (Belon et al., 2003). This can be explained by the fact that readily available family labour will allow for the timely execution of important farm activities such as fertilization and weeding, thus, contributing to higher yields. Besides, most farmers are financially constrained and thus, the availabilities of family labor will ease hiring of labour. Farm size has been reported to have a positive and significant relationship with technical efficiency (Tewe et al., 2003). One serious problem facing Nigeria today is chronic and transitory food insecurity (World Bank, 2003). Sweet potato is highly regarded as a food security crop and it is the most productive crop among all the other staple crops and tolerates occasional dry spells and yields even on less fertile soil in contrast to other crops such as maize (Woolfe, 2002; Zuraida, 2003). In a study carried out by World Bank (2003) it opined that, despite the fact that Nigeria was found to be the second highest producer of sweet potato in Africa, it was ranked $17^{\text {th }}$ in terms of output produced per land area, suggesting that sweet potato producers in Nigeria are quite inefficient in relation to farmers in other African countries. There is great need to improve the national production from over 1 million to 5 million tons per annum (World Bank, 2003). In Nigeria the output from sweet potato production is low and therefore there is need to empirically investigate factors that affect farm efficiency and productivity. This research determines factors of farm efficiency that can boost the level of farm productivity. It would add to the existing body of knowledge in rural sociology and economics of root crop production. It will also provide policy makers, development planners and other stakeholders with necessary data and insight for effective and sustainable policies and programmes that would facilitate and boost farm productivity and efficiency. Therefore, this study analyzes the technical efficiency of sweet potato production, while attempting to address the following research questions;

- What are the socioeconomic characteristics of the respondents?

- What is the technical efficiency of sweet potato production?

- What is the efficiency index among sweet potato farmers

- What are the constraints of sweet potato production?

$\mathrm{H}_{0}$ : There is no significant relationship between inputs and output in sweet potato production.

\section{Material and Methods}

\section{Study Area}

This study was carried out in Bokkos Local Government Area (LGA) of Plateau State, Nigeria. It has a total area of $1682 \mathrm{~km}^{2}$ and located between latitude $9^{\circ} 15^{\prime} \mathrm{N}$ and $8^{\circ} 3^{\prime} \mathrm{E}$, with a total projected population of 392,026 in
2016 (FAOSTAT, 2007). The Local Government is made up of 8 districts which include; Mushere, Daffo, Richa, Sha, Manguna, Toff, Kamoi and Bokkos. The LGA is located at the central region of Plateau State and it is surrounded by rocks and scattered vegetation. Its Annual rainfall averages from $600 \mathrm{~mm}-1000 \mathrm{~mm}$, with average temperatures of about $24^{\circ} \mathrm{C}-29^{\circ} \mathrm{C}$ annually (FAOSTAT, 2007). The major crops cultivated in the study area are Irish potato, sweet potato, cocoyam, maize and red beans.

\section{Sampling Technique}

Multistage sampling technique was used in selecting the respondents for the study. The first stage involved the Purposive selection of Bokkos LGA due to the prevalence of sweet potato production in the study area. The second stage involved the selection of three (3) districts out of eight (8) in the study area due to the prevalence of sweet potato farmers in the selected districts (Daffo, Sha and Bokkos districts). The third stage involved the collection of a compiled list of sweet potato farmers from Plateau state ADP extension agent at the LGA secretariat. In the last stage, using the list of estimated population of sweet potato farmers in the selected districts, respondents were randomly selected using 0.2 sampling proportion. Based on the foregoing, 94 respondents were randomly selected for the study. Table 1 presents the sample frame distribution.

Table1. Sample frame

\begin{tabular}{l|lrr}
\hline $\begin{array}{c}\text { Selected } \\
\text { Districts }\end{array}$ & Communities & $\begin{array}{c}\text { Sample } \\
\text { Frame }\end{array}$ & $\begin{array}{c}\text { Sample } \\
\text { size }\end{array}$ \\
\hline \multirow{3}{*}{ Daffo } & Ganda & 135 & 27 \\
& Magi & 64 & 13 \\
& Ngajul & 37 & 7 \\
\multirow{3}{*}{ Bokkos } & Kunnet & 66 & 13 \\
& Mangar & 35 & 7 \\
Sha & Tarangol & 34 & 7 \\
Total & Manguna & 61 & 12 \\
Source: Plar & Tar & 38 & 8 \\
& 08 & 470 & 94 \\
\hline
\end{tabular}

Source: Plateau State ADP, 2017

\section{Validation of the Research Instrument}

Content validity was used to measure the adequacy of the instrument items in this study. Content validity in this context sought to determine the relevance and adequacy of items included in the instruments. Using the Jury Method (Kerlinger, 1973), the entire instrument was subjected to the scrutiny of relevant experts. Each of the experts was requested to independently give his expert opinion on the relevance and adequacy of the items with respect to the objectives of the study. Various questions of the data collection instrument were scrutinized in terms of how relevant they are to the specific objectives of the study as well as how the prepared questions exhaustively cover the specific objectives of the study. Furthermore, the data collection instrument was examined against the background of its adequacy in regard to the accomplishment of the objectives of the study. 


\section{Instrument Reliability Test}

An instrument is considered reliable when it consistently produces the same result when applied to the same sample many times (Osuala, 2005). The test-retest method of affirming instrument reliability was employed for this study. It was computed by calculating the correlation coefficient between two distributions of test scores obtained at two different times on the same respondents. The instrument was trial tested on 20 respondents drawn from two districts in the Local Government Area viz: Daffo and Bokkos. The information obtained from the responses to the instrument were analysed using product-moment correlation analysis. High value of mean product-moment correlation coefficient of 0.735 indicated high reliability of the instrument.

\section{Method of Data Collection}

Primary data were collected from the sweet potato farmers in the study area, with the use of structured questionnaires in line with the specific objectives of the study.

\section{Analytical Techniques}

Descriptive statistics (such as frequency distribution, percentages and mean) was used to analyze objectives $i$ and iv, while the stochastic frontier production model was used to analyze objective ii and iii.

\section{Stochastic Frontier Production}

The Stochastic frontier approach is parametric and is sensitive to the choice of functional form and accounts for random errors. In this approach all deviations from the frontier are due to random effects and inefficiency. Efficiency in resource use must be sustained in order to improve productivity and maximize farm output. Technically efficient production is defined as the maximum quantity of output attainable by a given input (Pitt and Lee, 1981). According to Njeru (2004); technical efficiency is the ability of a firm to maximize output for a given set of resource inputs. Farm efficiency and productivity are indicators of agricultural production (Cechura et al., 2014). The efficiency, with which farmers use available resources and improved technologies, is important in agricultural production (Rahji, 2005). The efficient use of farm resources is germane for agricultural sustainability (Goni et al., 2013) and a prerequisite for optimum farm production since inefficiency in resource use can distort food availability and security (Etim et al., 2005). Efficiency measurement is germane in production studies. Inefficiency in the use of available scarce resources has been the bane of increased food production. According to Njeru (2004), technical efficiency is the ability of a firm to maximize output for a given set of resource inputs. Agricultural economists always provide the guidance to farmers about efficient utilization of inputs. Efficient utilization of inputs is also important for food security (Irz et al., 2010). The modeling and estimation of stochastic frontier production functions are useful to provide information about the relationship between the amount of output and the inputs of production, given the level of technology involved. In recent years, stochastic frontier models in agricultural economics have been used. The stochastic frontier model was originally proposed for the analysis of the panel data by Battese and Coelli (1995). The stochastic frontier production model is estimated using the maximum likelihood estimation procedure (MLE) (Battese and Corra, 1977). The technical efficiency of an individual firm is defined in terms of the observed output (Yi) to the corresponding frontier output $\left(\mathrm{Yi}^{*}\right)$ given the available technology as specified in equation (1) and (2);

$$
\begin{aligned}
& \mathrm{TE}_{\mathrm{i}}=\mathrm{Yi} / \mathrm{Yi}^{*} \\
& \mathrm{TE}_{\mathrm{i}}=\mathrm{f}(\mathrm{xi}: \beta) \exp (\text { vi-ui)/f(xi: } \beta) \exp (\text { vi) }-\exp (-u i)
\end{aligned}
$$

So that $0 \leq \mathrm{TE}_{\mathrm{i}} \leq 1$

Therefore, the technical inefficiency is equal to 1-TE.

However, a general stochastic frontier production function for the cross-sectional data, which is considered in this paper, is defined implicitly in equation (3);

$$
\mathrm{Yi}=\beta \mathrm{i} \mathrm{Xi}+\mathrm{Vi}-\mathrm{Ui}
$$

Where;

$\mathrm{Y}_{\mathrm{i}}=$ denotes the output for the $\mathrm{i}^{\text {th }}$ sample farm;

$\beta \mathrm{i}=$ vector of unknown parameters to be estimated;

$\mathrm{X}_{\mathrm{i}} \quad$ = vector of explanatory variables for the $\mathrm{i}^{\text {th }}$ farm;

$\mathrm{Vi}=$ independent and identically distributed random errors which have normal distribution with unknown variance $\alpha^{2}$

$\mathrm{U}_{\mathrm{i}}=$ non-negative unobservable random variables associated with the technical inefficiency of production, such that for a given technology and levels of inputs, the observed output falls short of its potential output.

Technical inefficiency effect model proposed in a study as adapted from Battese and Coelli (1995) is implicitly presented in equation (4);

$$
\mathrm{U}_{\mathrm{it}}=\delta_{\mathrm{o}}+\delta_{\mathrm{i}} \mathrm{Z}_{\mathrm{it}}
$$

Where;

$\mathrm{U}_{\mathrm{it}}=$ Technical inefficiency

$\delta_{0} \quad=$ vector of unknown parameters;

$\delta_{\mathrm{i}} \quad=$ vector of parameters to be estimated; and

$\mathrm{Z}_{\mathrm{it}}=$ explanatory variables associated with the technical inefficiency effects.

The stochastic frontier production function model was employed to analyze objective (ii). The stochastic production function with a multiplicative disturbance term is presented in equation (5);

$$
Y=f(X \beta)+e_{i}
$$

Where $\mathrm{Y}$ is the farm output in $\mathrm{kg}, \mathrm{X}$ is a vector of input quantities; $\beta$ is a vector of parameters and $\mathrm{e}$ is a stochastic disturbance term consisting of two independent elements $\mathrm{U}$ and $\mathrm{V}$, given by:

$$
\mathrm{e}_{\mathrm{i}}=\mathrm{v}-\mathrm{u}
$$

The empirical model stochastic frontier production function used in this study is specified in a double log form of Cobb- Douglas production function. The Cobb Douglas 
function is very useful in empirical analysis. The partial elasticity's are equal to each of the parameters and when linearized in $\log$, the function is easy to fit and the coefficients are direct elasticity's. The Cobb- Douglas production function is specified in equation (7);

$$
\operatorname{In} Y i=\beta_{0}+\beta_{1} \operatorname{In} X_{1}+\beta_{2} \operatorname{In} X_{2}+\beta_{3} \operatorname{In} X_{3}+\beta_{4} \operatorname{In} X_{4}+\beta_{5} \operatorname{In} X_{5}+V i-U_{i}
$$

Where;

In = natural logarithm to base e,

$\mathrm{Yi}=$ output of sweet potato $(\mathrm{kg} / \mathrm{ha})$

$\mathrm{V}_{\mathrm{i}}=$ random error due to mis-specification of the model and variation in output due to exogenous factors outside the farmer's control.

$\mathrm{U}_{\mathrm{i}}=$ technical inefficiency effects which captures deviation from the frontier.

$\beta_{\mathrm{o}}=$ intercept

$\beta_{1}-\beta_{5}=$ Unknown parameters which are to be determined.

$\mathrm{X}_{1} \quad$ = farm size measured in hectares (ha);

$\mathrm{X}_{2}=$ quantity of seed used (number of vine cuttings/ha);

$\mathrm{X}_{3}=$ labour measured in man-days;

$\mathrm{X}_{4}=$ quantity of fertilizer measured in kilogram per hectare $(\mathrm{kg} / \mathrm{ha})$;

$\mathrm{X}_{5} \quad$ = quantity of herbicides applied measured in litres per hectare (lt/ha)

\section{Technical Inefficiency Effect Model}

The average level of technical inefficiency measured by the truncated normal distribution has been assumed to be a function of socioeconomic factors and internal transaction costs. In the inefficiency effect model, a positive sign of an estimated parameter implies that the associated variable has a negative effect on efficiency but positive effect on inefficiency and vice versa. It is assumed that these inefficiency effects are independently distributed and $U_{i}$ arises by truncation (at zero) of the normal distribution with mean $U_{i}$ and variance $\alpha_{\mathrm{u}}$, where $U_{i}$ is the technical inefficiency and its determinants in crop production specified in equation (8);

$$
\mathrm{U}_{\mathrm{i}}=\alpha_{0}+\alpha_{1} \mathrm{Z}_{1}+\alpha_{2} \mathrm{Z}_{2}+\alpha_{3} \mathrm{Z}_{3}+\alpha_{4} \mathrm{Z}_{4}+\alpha_{5} \mathrm{Z}_{5}+\alpha_{6} \mathrm{Z}_{6}+\alpha_{7} \mathrm{Z}_{7}+\mathrm{w}_{\mathrm{i}}
$$

Where:

$\mathrm{Ui}=$ technical inefficiency effects of the ith farmer;

$\alpha_{\mathrm{o}}=$ intercept

$\alpha_{1}-\alpha_{7}=$ parameters to be estimated;

Where:

$\mathrm{Z}_{1} \quad=$ Farm capital measured in (naira);

$Z_{2}=$ Education measured in years;

$\mathrm{Z}_{3}=$ Access to formal credit $($ Yes $=1$, No $=0$ );

$Z_{4}=$ Farm experience measured in years;

$\mathrm{Z}_{5}=$ Extension contact $(\mathrm{Yes}=1, \mathrm{No}=0)$

$\mathrm{Z}_{6}=$ Membership of cooperatives/farmers association (Yes=1, $\mathrm{No}=0$ )

$\mathrm{Z}_{7} \quad=$ Household size (population)

$\mathrm{w}_{\mathrm{i}}=$ is the random variable which is defined by the truncation of the normal distribution with zero mean and variance.

$\mathrm{Zi}=\mathrm{is}$ expected to be negatively related to the level of inefficiency in sweet potato production

\section{Results and Discussion}

\section{Socioeconomic Characteristics of Sweet Potato Farmers}

Age of the Respondents

Table 2 revealed that most $(56.4 \%)$ of the respondents were within the age bracket of $\leq 39$ years; suggesting that most of the respondents were in their economically productive age bracket. The mean age of the respondents was 41years. This result implies a great prospective for sustainable sweet potato production in the study area. The result in Table 2 reveals that the farmers were strong, agile and active and can participate adequately in farming activities. Age is expected to have negative influence on the respondent's participation in improved sweet potato production that is why younger farmers are more active in the production of this crop. This result agrees with the findings in a study carried out by Amaza, 2007 and Akoneda (2009), who also reported similar results of the age of farmers engaged in agricultural production.

Gender of the Respondents

Table 3 revealed that most $(57.4 \%)$ of the respondents in the study area were male, while $42.6 \%$ are females; this indicates that the respondents were predominantly men; hence gender was also an essential socioeconomic factor that influences access to farm assets and resources agricultural production in Nigeria. This result agrees with the findings in a study carried out by Amaza, 2007 on farmer's demography.

Farm size

Table 4 revealed that most $(63.8 \%)$ of the farmers had farm holdings of $\leq 1.9$ ha, $25.5 \%$ of had farm holdings of 2.0-3.9 ha, while $10.7 \%$ constitutes farmers with $\geq 4.0$ ha. The mean farm size was $1.3 \mathrm{ha}$, implying that most of the farmers in the study area were producing at subsistent level and the likely implication of this is low farm output. This result agrees with the findings in a study carried out by Amaza, 2007 and Belon et al., 20003 on farmer's demography.

\begin{tabular}{|c|c|c|}
\hline Age (years) & Frequency & Percentage (\%) \\
\hline$\leq 39$ & 53 & 56.4 \\
\hline $40-59$ & 31 & 33 \\
\hline$>60$ & 10 & 10.6 \\
\hline Mean age $=41.4$ & & \\
\hline
\end{tabular}

Table 2. Distribution based on the Age of the Respondents

Table 3. Distribution based on the Gender of the Respondents

\begin{tabular}{l|cc}
\hline \multicolumn{1}{c|}{ Gender } & Frequency & Percentage (\%) \\
\hline Male & 54 & 57.4 \\
Female & 40 & 42.6 \\
\hline
\end{tabular}

Source: field survey 2017

Table 4. Distribution of the respondents based on their farm size

\begin{tabular}{l|cc}
\hline \multicolumn{1}{c|}{ Farm size (ha) } & Frequency & Percentage (\%) \\
\hline$\leq 1.9$ & 60 & 63.8 \\
$2.0-3.9$ & 24 & 25.5 \\
$\geq 4.0$ & 10 & 10.7 \\
\hline Mean = 1.3ha & \multicolumn{2}{l}{} \\
\hline
\end{tabular}

Source: field survey 2017 


\section{Household Size of the Respondents}

Table 5 revealed that most $(59.6 \%)$ of the respondents had a household population of $\leq 9$ people. The respondents have a mean household size of 7 people per household. The larger the size of the household the more labour supply for farm activities. This implies that households in the study area had adequate labour supply to embark on expansionary farming activities which will result to increased farm efficiency and productivity at low labour cost. This result agrees with the findings in a study carried out by Amaza, 2007 and Coelli et al., 2002 on farmer's demography.

\section{Farm Labour Supply}

Table 6 revealed that most $(60.6 \%)$ of the respondents used both family and hired labour in carrying out various operations of their farm activity; $21.3 \%$ used mainly family labour while hired labour was $(18.1 \%)$ for their sweet potato farming activities. For those that supplement the hired labour with family labour, family labour was used in operations such as planting, fertilizer application and harvesting while hired labour was used mainly for land clearing, ridging, weeding and spraying. A majority of the respondents claimed to have experienced shortage of labour during land clearing and ridging leading to a high cost of performing such operations. The average labour input per household is 124 man-day ha-1, out of which $52 \%$ was family labour. This result agrees with the findings in a study carried out by Amaza, 2007 and Cechura et al., 2014 on farmers demography.

\section{Farming System}

Table 7 revealed that most $(78.7 \%)$ of the respondents in the study area were subsistent farmers, while $21.3 \%$ were commercial farms which were mostly communal farms; This predominant farm system was attributable to the prevalent tenure policies which caused fragmentation of most potential farms lands; resulting to a prevalence of small farm holdings among most farmers in the study area. This result agrees with the findings in a study carried out by Amaza, 2007 on farmer's demography.

\section{Management Practice}

Table 8 revealed that most $(53.2 \%)$ of the respondents in the study area adopted mixed cropping systems, while $46.8 \%$ adopted monocropping systems. This predominant cropping system is attributable to the farm size of the respondents; hence most farms combined cultivation of sweet potato production with other crops so as to maximize a variety of farm output relative to their small farm holdings in the study area. This result agrees with the findings in a study carried out by Amaza, 2007 and Etim et al., 2005 on farmer's demography.

\section{Farm Capital}

Table 9 revealed that most $(71.3 \%)$ of the respondents in the study area used their personal savings to finance their farm activities. Capital from this source is usually very small and this may be one of the reasons why the farmers cultivated at very subsistent level with inadequate capacities to scale-up their farm activities, while $28.7 \%$ got credit from other sources to supplement their personal savings. Agricultural credit enables farmers to augment their farm capital. The mean farm capital per respondents was $\$ 71,500$. This result agrees with the findings in a study carried out by Amaza, 2007 on farmers demography.

\section{Access to Credit}

Table 10 revealed that most $(81.9 \%)$ of the respondents in the study area do not have access to agricultural credit. Agricultural credit helps farmers to augment their farm capital; however, respondents in the study were excluded from financial services due to the absence of financial institutions in the study area. Adequate funding is required by farmers to finance all sweet potato production activities. However, a large number of farmers face serious shortage of funds to finance their sweet potato production activities, which in turn limits their level of production. This low access to credit could also be attributed to the fact that government seldom grants financial credit to large number of farmers. In a study carried out by Ekong (2003) it was asserted that credit is a very strong factor that is needed to acquire or develop any enterprise; its availability could determine the extent of production capacity.

Table 5. Distribution based on the Household Size of the Respondents

\begin{tabular}{l|cc}
\hline \multicolumn{1}{c|}{ Household size } & Frequency & Percentage (\%) \\
\hline$\leq 9$ & 56 & 59.6 \\
$10-19$ & 30 & 31.9 \\
$\geq 20$ & 8 & 8.5 \\
\hline Mean $=7$ & & \\
\hline \multicolumn{2}{l}{ Source: field survey 2017 }
\end{tabular}

Table 6. Distribution based on the Farm Labour Supply of the Respondents

\begin{tabular}{l|cc}
\hline \multicolumn{1}{c|}{ Labour Supply } & Frequency & Percentage (\%) \\
\hline Family labour & 20 & 21.3 \\
Hired labour & 17 & 18.1 \\
BM & 57 & 60.6 \\
\hline
\end{tabular}

BM: Both Mean: 124 man-day ha-1, Source: field survey 2017

Table 7. Distribution based on the Farming System of the Respondents

\begin{tabular}{l|cc}
\hline Farm system & Frequency & Percentage (\%) \\
\hline Subsistent & 74 & 78.7 \\
Commercial & 20 & 21.3 \\
\hline
\end{tabular}

Source: field survey 2017

Table 8. Distribution based on the Management Practice of the Respondents

\begin{tabular}{l|cc}
\hline Practice & Frequency & Percentage (\%) \\
\hline Monoculture & 44 & 46.8 \\
Polyculture & 50 & 53.2 \\
\hline
\end{tabular}

Source: field survey 2017

Table 9: Distribution based on the Management Practice of the Respondents

\begin{tabular}{l|cc}
\hline \multicolumn{1}{c|}{ Source } & Frequency & Percentage (\%) \\
\hline Savings & 67 & 71.3 \\
Credit Mean: $¥ 71,500$ & 27 & 28.7 \\
\hline Source: field survey 2017 &
\end{tabular}

Source: field survey 2017

Table 10. Distribution based on Respondents Access to Credit

\begin{tabular}{l|ll}
\hline Credit & Frequency & Percentage (\%) \\
\hline Yes & 77 & 81.9 \\
No & 17 & 18.1 \\
\hline
\end{tabular}

Source: field survey 2017 


\section{Membership of Cooperative of Respondents}

Table 11 revealed that most $(84 \%)$ of the respondents do not belong to any cooperative society. This affects the ability to boost levels of farm efficiency and output through synergy in agricultural resource utilization among farmers. Also, membership of farm associations or cooperative societies avail farmers the opportunity to have more access to agricultural credit, receive agricultural inputs at subsidized rates and for effective information dissemination on improved agricultural practices and technology that boost levels of farm efficiency and output. Consequently, farmers who belong to the cooperative societies enjoy the benefits accruable to members through the pooling of resources together for better expansion of their production frontier; efficient and effective management of resources and for profit maximization. In a study carried out by Wilson et al. (2001) and Ekong (2003) it was reported that membership of cooperative societies has advantages of accessibility to micro-credit, input subsidy and also as avenue in cross breeding ideas and information.

Farm Output of the Respondents

Table 12 revealed that most $(80.9 \%)$ of the respondents obtained a farm output of $\leq 4.9$ tons per hectare. The respondents had a mean farm output of 3.1 tons $\mathrm{ha}^{-1}$. This low level of farm output can be attributable to their farm size as well poor resource utilization among the farmers which can maximize farm output. This implies that majority of the farmer where producing at subsistent level in the study area. This result agrees with the findings in a study carried out by Amaza, 2007 and Alene and Hassan, 2003 on farmer's demography.

\section{Farm Output of the Respondents}

Table 13 revealed that most $(79.8 \%)$ of the respondents used $\leq 999$ grams of seed per hectare. The mean quantity of seeds used by the respondents in the study area was 700 grams. This was adequate enough considering the relatively small farm size of the respondents. However, the varieties of seeds adopted were of local variety which affected the level of productivity and yield; suggesting low output from sweet potato farms in the study area. This result agrees with the findings in a study carried out by Awudu and Richard, 2001 on farmer's demography.

\section{Educational Level of the Respondents}

Table 14 revealed that most $(44.7 \%)$ of the respondents attained primary education. This implies that majority of the respondents were literates and had basic educational backgrounds, which is in turn could enhance their productive capacities. Research has shown that education enables farm households in rural areas to adopt new agricultural methods, cope with risk, respond to market signals and improve agricultural productivity (Njeru, 2004).

\section{Farming Experience of the Respondents}

Table 15 revealed that most $(54.3 \%)$ of the respondents had 10-19 years of farming experience. The mean farming experience of the respondents was 18 years. This indicates that the farmers in the study area had adequate experience in the cultivation of sweet potatoes; their farming experience was also major determinant factor in sweet potato production. The result opined that the respondents had adequate experience necessary for increased production. This shows that the managerial ability of farmers can be inferred to be reasonably good. This is because the more experienced a farmer is the more efficient his decision making processes and willingness to take risks associated with adoption of innovation to increase farm productivity. Farming experience is the act of gaining knowledge through constant practicing of skill, which brings about specialization (Belon et al., 2003). Experienced farmers have the ability to use modern agricultural technology and practices. In a study carried out by Tewe et al. (2003) it was reported that experience enhances more efficient use of scarce resources by smallscale farmers in his study of socioeconomic determinants of output and profit levels of small-holder rice production systems in Abia State.

Table 11. Distribution based on Membership of Cooperatives

\begin{tabular}{l|ll}
\hline Membership & Frequency & Percentage (\%) \\
\hline Yes & 15 & 16 \\
No & 79 & 84 \\
\hline
\end{tabular}

Source: field survey, 2017

Table 12. Distribution based on Farm Output in Tons per Hectare (Tons ha ${ }^{-1}$ )

\begin{tabular}{l|cc}
\hline Output level $\left(\right.$ Tons ha $\left.^{-1}\right)$ & Frequency & Percentage $(\%)$ \\
\hline$\leq 4.9$ & 76 & 80.9 \\
$5-9.9$ & 13 & 13.8 \\
$\geq 10$ & 5 & 5.3 \\
Mean $=3.1$ & & \\
\hline Source: field survey 2017
\end{tabular}

Table 13. Distribution based on quantity of seed (vine) used per Hectare (gram ha-1)

\begin{tabular}{l|ll}
\hline Seed quantity $\left(\right.$ gram ha $\left.^{-1}\right)$ & Frequency & Percentage $(\%)$ \\
\hline$\leq 999$ & 75 & 79.8 \\
$1000-2999$ & 14 & 14.9 \\
$\geq 3000$ & 5 & 5.3 \\
\hline Mean =700 grams & \multicolumn{3}{l}{} \\
\hline
\end{tabular}

Source: field survey 2017

Table 14. Distribution of the respondents based on their educational level

\begin{tabular}{l|cc}
\hline \multicolumn{1}{c|}{ Educational level } & Frequency & Percentage (\%) \\
\hline Non-formal & 8 & 8.5 \\
Primary & 42 & 44.7 \\
Secondary & 29 & 30.9 \\
Tertiary & 15 & 16 \\
\hline
\end{tabular}

Source: field survey 2017

Table 15. Distribution based on the Farming Experience of the Respondents

\begin{tabular}{l|cc}
\hline Farming experience & Frequency & Percentage (\%) \\
\hline$\leq 9$ & 23 & 24.5 \\
$10-19$ & 51 & 54.3 \\
$\geq 20$ & 20 & 21.3 \\
\hline Mean = 18years & \multicolumn{2}{l}{} \\
\hline \multicolumn{2}{l}{}
\end{tabular}




\section{Agrochemical Application}

Table 16 revealed that most $(83 \%)$ of the respondents in the study area applied herbicides on their farms, while $17 \%$ used pesticides on their farms. An average of 10 liters ha- 1 of herbicides was applied by the respondents on their sweet potato farms. This results indicates that majority of the respondents applied herbicides on their farms for the purpose of weed management and control in the study area. Agrochemicals are expensive and not readily available in the study area; hence they need for more extension activities to sensitive farmers on the use of these agrochemicals and subsidization of agricultural input prices is also required. This result corroborates with the findings of Ajetomba (2005) and Olarinde et al. (2005) who also reported similar results on agrochemical application in arable crop production.

\section{Fertilizer Application}

Table 17 revealed that most $(89.4 \%)$ of the respondents in the study area applied organic fertilizers on their farms, while $10.6 \%$ used inorganic fertilizers on their farms. An average of 250 kilogram $(\mathrm{kg}) \mathrm{ha}^{-1}$ of inorganic fertilizer was applied by the respondents on their sweet potato farms. This results indicates that majority of the respondents applied organic fertilizers on their farms; suggesting a prevalence of organic farming activities among respondents in the study area. Application of organic fertilizers can be attributable to high cost of procurement and non-availability of inorganic fertilizers as compared to organic fertilizers, which were relatively cheaper and more accessible to the farmers. However, the use of fertilizer among the respondents was grossly inadequate, some respondents also claimed that they have fertile land that does not require fertilizer application. This result corroborates with the findings in a study carried out by Ajetomba (2005) and Olarinde et al. (2005) who reported similar results on fertilizer application in arable crop production.

\section{Extension Contact}

Table 18 revealed that most $(87 \%)$ of the respondents in the study area had no access to extension. This indicates that they respondents do not have access to agricultural information and technology that will boost their level of farm efficiency and output. Based on their literacy levels the respondents would have easily adopted improved agricultural technology. Extension contact is germane to build farmers capacity, resilience to agricultural risks, poverty reduction strategies, innovation and practices that will ensure sustained farm efficiency and food security in the study area. This result agrees with the findings in a study carried out by Belon et al. (2003) on farmer's demography.

\section{Technical Efficiency of Sweet Potato Production}

The estimates of the parameters of the stochastic frontier model are presented in Table 18. The estimated value of the coefficient of Sigma square $\left(\delta^{2}\right)(0.699)$ was positive and significantly different from zero at $5 \%$ $(\mathrm{P}<0.05)$ level of probability. This indicates a goodness of fit of the model and correctness of the specified distributional assumptions of the composite error terms for the regression analysis. The value of gamma $(\gamma)$ is estimated to be $27 \%$ and not statistically significant. This is consistent with the theory that true $\gamma$-value should be greater than zero. This implies that $27 \%$ of random variation in the yield of the farmers was due to the farmers' inefficiency on their respective farms and not as a result of random variability. Since these factors are under the control of the farmer, reducing the influence of the effect of $\gamma$ will greatly enhance the technical efficiency of the farmers and improve their yield. The gamma $\gamma$ indicates the systematic influences that are unexplained by the production function and the dominant sources of random error. This means that the inefficiency effects make significant contribution to the technical inefficiencies of sweet potato farmers; hence the technical inefficiency effects are significant in the estimated model. The study revealed that the generalized log likelihood function was 88.751. The log likelihood function implies that inefficiency exist in the data set. The estimated ratio of the $\mathrm{L} / \mathrm{R}$ test was 0.579 . The $\mathrm{L} / \mathrm{R}$ test assessed the goodness of fit of the statistical models based on the ratio of their likelihoods; it compared the deterministic production and stochastic function in selecting the appropriate functional form (cobb-Douglas); hence the estimated ratio was significantly different from one and equivalently its natural logarithm was significantly different from zero $(0<1)$; indicating a goodness of fit of the frontier model. Thus the null hypothesis was rejected. The average technical efficiency for the farmers is 0.62 implying that, on the average the respondents were able to obtain $62 \%$ of potential output from a given mixture of production inputs. Thus, in a short run, there is minimal score of increasing the efficiency by $38 \%$, through adoption of modern technology and techniques in sweet potato production.

Table 16. Distribution based on Agrochemicals Applied by the Respondents

\begin{tabular}{l|cc}
\hline Agrochemical & Frequency & Percentage (\%) \\
\hline Herbicide & 78 & 83 \\
PM & 16 & 17 \\
\hline \multicolumn{2}{l|}{ PM: Pesticide Mean quantity 10 liters ha-1, Source: field survey 2017 }
\end{tabular}

Table 17. Distribution based on Fertilizer Applied by the Respondents

\begin{tabular}{l|ll}
\hline Agrochemical & Frequency & Percentage (\%) \\
\hline Organic & 84 & 89.4 \\
IM & 10 & 10.6 \\
\hline
\end{tabular}

IM: Inorganic Mean quantity $250 \mathrm{~kg} \mathrm{ha}^{-1}$, Source: field survey 2017

Table 18: Distribution based on the Extension Contact of the Respondents

\begin{tabular}{l|cc}
\hline Extension contact & Frequency & Percentage (\%) \\
\hline No & 74 & 78.7 \\
Yes & 20 & 21.3 \\
Total & 92 & 100 \\
\hline Source: field survey, 2017
\end{tabular}

Source: field survey, 2017

In consonance with a priori expectation, the coefficients of sweet potato seeds (vines) (0.362) and labour (0.439) were positive and statistically significant at $5 \%(\mathrm{P}<0.05)$ level of probability; implying that an increase in these variables will increase the level of output. This result is in line with the studies carried out by carried out by Okonkwo and Okoli (2000), Amaza (2007) and Coelli et al., (2002), who reported positive correlation in input- 
output relationships in crop production. However, against a priori expectation, the coefficients of farm size (-1.333); was negative but statistically significant.

Farm size: the coefficients of farm size (-1.333), was negative but statistically significant at $5 \%(\mathrm{P}<0.05)$ level of significance; suggesting an inverse relationship with farm output. This implies that an increase in farm size no positive impact on the output of sweet potato in the study area. In a study carried out by Coelli et al. (2002), it was reported that smaller farms were economically more efficient than larger farms. If farm size is small, farmers are able to combine their resources better (Ogundari and Ojo, 2006).

Seed: The estimated coefficient for sweet potato seed (vines) was 0.362 which is positive and statistically significant at $5 \%$ level. This implies that a $1 \%$ increase of this variable will increase sweet potato output by $0.36 \%$. The significance of seed quantity is however, due to the fact that seed determines to a large extent the output obtained. If correct seed rates and quality of seeds are not used, output will be low even if other inputs are in abundance. This result is in line with the studies carried out by (Etim et al., 2005; Ben- Belhassen, 2002; Belon et al., 2003) who observed that the estimated coefficient of seed and labour inputs were positive and significant at $1 \%$ level implying that the more seed is applied and the more labour employed the better the output of sweet potato.

Labour: The coefficient of labour was 0.439 which is positive and statistically significant at 5\% level of probability. This shows the importance of labour in sweet potato farming in the study area. The implication is that a $1 \%$ increase in labour supply may increase the output of sweet potato by $0.44 \%$. This is in line with several studies carried out by Amaza (2007) and Coelli et al. (2002) which revealed the importance of labour in farming, particularly in developing countries where mechanization is rare on small scale farms. In the study area, farm labour plays a crucial role in virtually all farming activities. This situation has variously been attributed to the practice of split-plot cropping on small scattered land holdings and lack of affordable equipment (Belon et al., 2003). This result is in line with the studies carried out by (Onyenweaku et al., 2004; Okonkwo and Okoli, 2000; Belon et al., 2003; Allen and Hassan, 2003) who observed that the estimated coefficient of seed and labour inputs were positive as expected and significant at $1 \%$ level implying that the more seed is applied and the more labour employed the better the output of sweet potato.

However, against a priori expectation, the coefficients of fertilizer (-0.452) and herbicides (-0.766) were negative but statistically significant at $5 \% \quad(\mathrm{P}<0.05)$ level of significance; suggesting an inverse relationship with farm output which is attributable to inadequate and improper application of fertilizer and herbicides by the respondents on their farms.

Most of the coefficients in the inefficiency model were negative. Generally, a negative sign on a parameter means that the variable reduces technical inefficiency, while a positive sign increases technical inefficiency. The inefficiency model revealed that the coefficient of farm capital (-0.172), education (-2.281), access to credit ($0.472)$, farming experience (-0.639), extension contact ($0.733)$ and membership of cooperatives (-0.396) were negative and statistically significant at $5 \%(\mathrm{P}<0.05)$ level of probability. This implies that increase in these variables may have the tendency of reducing the inefficiency level in sweet potato production among farmers in the study area.

Table 19. Stochastic Frontier Analysis of efficiency in Sweet Potato Production

\begin{tabular}{|c|c|c|c|c|}
\hline Variable & Parameter & Coefficient & Standard error & T-ratio \\
\hline \multicolumn{5}{|l|}{ Efficiency model } \\
\hline Constant & $\beta_{0}$ & $2.721 * *$ & 0.983 & 2.768 \\
\hline $\operatorname{Farm} \operatorname{size}\left(\mathrm{x}_{1}\right)$ & $\beta_{1}$ & $1.333 * *$ & 0.472 & 2.824 \\
\hline $\operatorname{Seed}\left(\mathrm{x}_{2}\right)$ & $\beta_{2}$ & $0.362 * *$ & 0.202 & 1.792 \\
\hline Labour $\left(\mathrm{x}_{3}\right)$ & $\beta_{3}$ & $0.439 * *$ & 0.164 & 2.676 \\
\hline Fertilizer $\left(\mathrm{x}_{4}\right)$ & $\beta_{4}$ & $-0.452 * *$ & 0.139 & -3.251 \\
\hline Herbicides $\left(\mathrm{x}_{5}\right)$ & $\beta_{5}$ & $-0.766 * *$ & 0.681 & 1.124 \\
\hline \multicolumn{5}{|l|}{ Inefficiency model } \\
\hline Constant & $\alpha_{0}$ & $2.273^{* *}$ & 0.891 & 2.551 \\
\hline Capital $\left(\mathrm{z}_{1}\right)$ & $\alpha_{1}$ & $-0.172 * * *$ & 0.055 & -3.127 \\
\hline Education $\left(\mathrm{z}_{2}\right)$ & $\alpha_{2}$ & $-2.281 * * *$ & 0.723 & -3.155 \\
\hline Experience $\left(\mathrm{z}_{3}\right)$ & $\alpha_{3}$ & $-0.639 * *$ & 0.218 & -2.931 \\
\hline Credit $\left(\mathrm{z}_{4}\right)$ & $\alpha_{4}$ & $-0.472 * *$ & 0.159 & -2.969 \\
\hline Extension $\left(\mathrm{z}_{5}\right)$ & $\alpha_{5}$ & $-0.733 * *$ & 0.289 & -2.536 \\
\hline Cooperative $\left(\mathrm{z}_{6}\right)$ & $\alpha_{6}$ & $-0.396 * *$ & 0.158 & -2.51 \\
\hline Household size $\left(\mathrm{z}_{7}\right)$ & $\alpha_{7}$ & $0.218^{\text {n.s }}$ & 0.161 & 1.354 \\
\hline \multicolumn{5}{|l|}{ Diagnostic statistic } \\
\hline Sigma -square & $\left(\sigma^{2}\right)$ & $0.699 * *$ & 0.251 & 2.784 \\
\hline Gamma & $(\gamma)$ & 0.271 & 0.282 & 0.961 \\
\hline Log likelihood function & $(1 / f)$ & -88.751 & & \\
\hline LR test & & 0.579 & & \\
\hline Number of observations & & 94 & & \\
\hline Mean efficiency & & 0.62 & & \\
\hline
\end{tabular}




\section{Farm Capital}

The coefficient of farm capital (-0.172) was negative but statistically significant at $5 \% \quad(\mathrm{P}<0.05)$ level of probability, suggesting that a $1 \%$ increase in farm capital will increase sweet potato yield by $0.17 \%$, suggesting that farm capital increases efficiency in sweet potato production. The negative sign indicates an inverse relationship with technical inefficiency. This implies that farmers with improved farm capital tend to be more efficient in their farm operations through increased capacity to acquire and adopt improved agricultural technology and inputs that will boost the level of their farm output. This result is consistent with the studies carried out by (Njeru, 2004; Battese and Corra, 1977; Belon et al., 2003; Shrestha et al., 2015) who reported that improved farm efficiency can be attributable to increase in farm capital.

\section{Educational Level}

The estimated coefficient of educational level (-2.281) was negative and statistically significant at $\mathrm{P}<0.05(5 \%)$ level of probability. The number of years spent in school is a proxy of the literacy level of the farmers. The results revealed an inverse relationship to technical inefficiency in sweet potato production. This implies that farmers with better education were technically more efficient; hence literacy increases farmer's capacity to adopt and efficiently utilize agricultural technology and information that tend to boost farm output. Increased level of education results in better evaluation of management systems, farm decision making and efficient input utilization. This result corroborates with the studies carried out by (Cechura et al., 2014; Awudu and Richard, 2001; Belon et al., 2003), who also reported that improved farm efficiency can be attributable to increase in the level of education. The positive correlation between education and technical efficiency is consistent with previous studies carried out by (Amaza and Maurice, 2005; Coelli et al., 2002; Amaza, 2007).

\section{Farming Experience}

The estimated coefficient of farming experience ($0.639)$ was negative and statistically significant at $\mathrm{p}<0.05$ $(5 \%)$ level of probability, suggesting that years of farming experience was positively correlated with farm efficiency; this indicates that an increase in the number of years in sweet potato production decreases technical inefficiency. An increase in efficiency may also be attributable to the experience they have gained over time especially with regard to production techniques and combination of resources. This result corroborates with the studies carried out by Amaza, (2007) who also reported a positive correlation between farming experience and farm output. Also, this is in line with the study carried out by Ogundari and Ojo (2006), and Awudu and Richard (2001); who opined that farming experience shows that farmers will be able to make sound decisions as regards resources allocation and management of their farms.

\section{Access to Agricultural Credit}

The estimated coefficient of Credit access (-0.472) was negative and statistically significant at $\mathrm{p}<0.05(5 \%)$ level of probability. Credit access revealed a positive relationship with technical efficiency. This implies that the farmers who have greater access to credit tend to be more efficient in production; hence they possess more capital for investments in farm assets. This agrees with the study carried out by Onyenweaku et al., 2004 and Belon et al., 2003 who reported similar findings of variables in the inefficiency effects model.

\section{Extension Contact}

The estimated coefficient of extension contact $(-0.733)$ was negative and statistically significant at $\mathrm{p}<0.05(5 \%)$ level of probability. Extension contact leads to more efficient transmission of information to farmers as well as enhancing the adoption of innovation. Extension contact is germane to build farmers capacity, resilience to agricultural risks and reduction strategies, improve access to innovation and practices that will ensure sustained farm efficiency and food security in the study area. This agrees with the study carried out by Amaza and Maurice, 2005 and Cechura et al., 2014 who reported similar findings of variables in the inefficiency effects model.

\section{Cooperative Membership}

The estimated coefficient of Cooperative membership $(-0.396)$ was negative and statistically significant at $\mathrm{p}<$ $0.05(5 \%)$ level of probability. Membership of cooperatives is positively and significantly related to technical efficiency. Membership of cooperatives enables the farmers to have access to agricultural information, credit and other inputs as well as enhanced ability to adopt innovations. This suggests that assumed benefits will only accrue to members of co-operative societies who may have pooled their resources together for expansion, efficiency and effective farm management. In a study carried out by Etim et al., (2005) and Cechura et al., (2014) Stated that membership of cooperative societies gives advantages of accessibility to microcredit, input subsidy and agricultural technology. Also, it serves as avenue for the exchange of ideas and agricultural information.

\section{Technical Efficiency Index}

The technical efficiency of sampled farmers was less than one $(<100 \%)$ implying that all the farmers in the study area are producing below maximum efficiency frontier. From the observed range of technical efficiency across the sampled farmers, the best farmer had a technical efficiency index of $0.91(91 \%)$, while the least farmer had a technical efficiency of $0.33(33 \%)$. A wide gap exists between the efficiency of most technically efficient farmer (91\%) and that of the least efficient farmer (33\%). This type of wide variation in farmer's specific efficiency levels is a common phenomenon in developing countries (Amaza, 2007). The result, however, indicates that great potential exists for the sweet potato farmers to further increase output through increased efficiency in resource utilization. The mean technical efficiency was $0.62(62 \%)$ implying that on the average, farmers in the study area were able to obtain average of $62 \%$ optimal output from a given mix of production inputs. The mean technical efficiency estimated indicates that the realized output could be increased by about $38 \%$ by adopting improved management practices and technology. The magnitude of the mean technical efficiency of the farmers is a reflection of the fact that most of the sampled farmers carry out sweet potato production using poor management practices; with inadequate adoption of modern agricultural technology. From this estimation, maximum technical efficiency is not yet achieved suggesting a need for more effort at improving 
efficiency of sweet potato farmers in the study area. The distribution of technical efficiency index of the farmers shows that, most $(45.7 \%)$ of the sweet potato farmers had efficiency index ranging between 0.41-0.50; this further emphasizes the need for the respondents to adopt improved management practices and technology that can boost their level of farm output and efficiency (Cechura, 2014). Thus, opportunity still exists for increasing productivity and income through increased efficiency in resource utilization.

Table 20. Distribution of Respondents based on their Technical Efficiency Index

\begin{tabular}{l|cc}
\hline \multicolumn{1}{c|}{ Efficiency index } & Frequency & Percentage $(\%)$ \\
\hline $0.31-0.40$ & 10 & 10.6 \\
$0.41-0.50$ & 43 & 45.7 \\
$0.51-0.60$ & 17 & 18.1 \\
$0.61-0.70$ & 12 & 12.8 \\
$0.71-0.80$ & 7 & 7.4 \\
$0.81-0.90$ & 3 & 3.3 \\
$0.91-1.00$ & 2 & 2.1 \\
Total & 94 & 100 \\
Minimum & 0.33 & \\
Maximum & 0.91 & \\
Mean & 0.62 & \\
\hline Sour Comp &
\end{tabular}

Source: Computed from MLE results 2017

Table 21. Constraints of sweet potato production

\begin{tabular}{|c|c|c|}
\hline Constraints & $\mathrm{F}$ & $\% *$ \\
\hline High cost of labour & 65 & 69.1 \\
\hline Financial constraints & 82 & 87.2 \\
\hline Poor storage facility & 71 & 75.5 \\
\hline Pest and diseases & 46 & 48.9 \\
\hline $\begin{array}{l}\text { Poor access to agricultural } \\
\text { technology/inputs }\end{array}$ & 53 & 56.4 \\
\hline Lack of extension contact & 34 & 36.2 \\
\hline $\begin{array}{l}\text { Low patronage due to predominance of } \\
\text { similar } \operatorname{crop}(s)\end{array}$ & 37 & 39.4 \\
\hline $\begin{array}{l}\text { High cost of agricultural } \\
\text { technology/inputs }\end{array}$ & 89 & 94.7 \\
\hline
\end{tabular}

\section{Constraints of Sweet Potato Production}

The result of Table 21 revealed that the constraints of sweet potato production in the study area include; high cost of agricultural technology/inputs $(94.7 \%)$; attributable to poor access and non-subsidization of productive resources. Also, most of the farmers wish to wait for government subsidized and qualitative fertilizer and inputs which are grossly inadequate. Financial constraints (87.2\%); attributable to poor access to financial institutions and agricultural credit among the respondents; hence their meager savings are not sufficient to cater for their farm activities in sweet potato production. Poor storage facilities (75.5\%); attributable to poor access to modern agricultural technology, high cost of labour (69.1\%); attributable to non-availability and inadequate supply of farm labour; family labour was predominantly used in the study area resulting in acute shortage of labour. According to the farmers, during active period of production-every household would have been engaged in his family farm work. The demand for labour is normally very high and expensive during the peak period of land clearing, ridging, harvesting, processing and weeding in the study area. Poor access to agricultural technology/inputs (56.4\%); attributable to non-availability of agricultural technology/inputs in the study area, according to the respondents they make use of seeds from their previous harvest which is not reliable and can jeopardize improved and sustainable productivity. Pest and diseases (48.9\%); attributable to the adoption of poor management practices among the respondents, the farmers also revealed that pest and diseases were responsible for pre-harvest and postharvest losses in sweet potato production in the study area. Low patronage due to predominance of similar crop(s) $(39.4 \%)$; attributable to increased demand for alternative root crops in the study area and poor access to market linkages to sell their agricultural produce. Lack of extension contact (36.2\%); attributable to poor and inadequate extension services in the study area. All the constraints identified by the farmers significantly affected sweet potato production in the study area. This result is in line with the study carried out by Cechura et.al. (2014); Ogundari and Ojo (2006); and Ben-Belhassen (2002), who opined similar constraints in crop production.

\section{Conclusion and Recommendations}

This study analyzed the technical efficiency of sweet potato production in Bokkos LGA of Plateau State, Nigeria. The results revealed that the socioeconomic characteristics of the respondents significantly affected their farm efficiency and level of farm output in sweet potato production in the study area. The variables in the stochastic frontier model significantly affected the technical efficiency and output of sweet potato production in the study area. This implies that efficient resource utilization in sweet potato production can increase the level of farm output in the study area. The efficiency index of the sweet potato farmers in the study area also revealed that they were not producing at optimal capacity. The constraints identified significantly affected sweet potato production in the study area. Based on the findings of this study, the following recommendations are made for policy actions to improve the technical efficiency of sweet potato production in the study area;

- Policies should be formulated that will subsidize agricultural input costs.

- Stakeholders should increase measures to sensitize farmers on appropriate application and utilization of agricultural resources.

- Formulation of policies to improve access to agricultural inputs and technology in sweet potato production.

- Formulation of policies that will ensure adequate market linkages for their agricultural produce.

- Formulation of policies that will ensure adequate farm labour supply.

- Formulation of polices to improve access to farm capital, agricultural credit and extension services for the sweet potato farmers.

- Sensitization of the sweet potato farmers on appropriate methods of fertilizer and agrochemical application and management. 
- Formulation of polices that'll improve the level of farm efficiency in sweet potato production in the study area.

- Sensitization of sweet potato farmers on modern agricultural practices, importance of cooperative formation and efficiency in resource utilization.

- Formulation of policies to encourage the development of indigenous storage and processing technologies in sweet potato production.

\section{References}

Adewumi MO, Adebayo FA. 2008. Profitability and technical efficiency of sweet potato production in Nigeria. Journal of Rural Development, 31(5): 105-120.

Adewuyi SA, Okunmadewa FY .2001. Economic Efficiency of Crop Farmers inKwara State, Nigeria. Nigerian Agricultural Development Studies 2(1): 45-47.

Adu-Kwarteng E, Otoo JA, Osei CK, Baning IS. 2002. Sweet potato: The Crop of the Future. Factsheet Published by the Communications and Extension Division of Crops Research Institute - Council for Scientific and Industrial Research, Ghana.

Aigner DJ, Lovell CAK, Schmidt P. 1977. Formulation and Estimation of Stochastic Frontier Function Models Journal of Econometrics 6: 21-37.

Ajetomba JO. 2005. Socio-economic characteristics and profitability of contact farmers in Oyo agricultural Zone in a deregulated economy. Journal of Social service 11(3):17718117.

Ajibefun IA, Battese GE, Daramola AG. 2002. Determinates of Technical Efficiency in mall holder Crops farming: Application of stochastic frontier production function. Quarterly Journal of International Agriculture 41(3): 225240.

Akoneda M. 2009. Sweet Potato in West Africa 'In' The sweet potato. LoebensteinG and G Thottaphy (eds) spring Science Business media B.V 2009. 456-457.

Alene DA, Hassan RM. 2003. Measuring the impact of Ethiopia's New Extension programmes on the productive efficiency of farmer. Paper presented at the 25th International Conference of Agricultural Economist, Durban, South Africa.

Amaza PS. 2007. Baseline Socioeconomic Survey Report Agriculture in Borno State, Nigeria. International Institute of Tropical Agriculture, Ibadan, PP. 84

Amaza PS, Maurice DC. 2005. Identification of Factors that influence Technical Efficiency in Rice- based Production Systems in Nigeria. Paper presented at the workshop on policies and Strategies for Promoting rice production and food security in sub-Saharan Africa7-9 Nov., 2005, Cotonou, Benin.

Awudu A, Richard E. 2001. Technical efficiency during Economic Reforms in Nicaragua: Evidence from farmholds Survey Data. Economic Systems 25: 125.

Azogu I, Olomo VO. 2002. "Processing Options for Roots and Tubers under the RTEP Initiative: Constraints and Opportunities. Paper presented at the PFT Workshop, Makurdi, 17 August 2002.

Battese G, Coelli T. 1995. "A Model for Technical Inefficiency Effects in a Stochastic Frontier Production Model for Panel Data," Empirical Economics, 20: 325-332.

Battese GE, Corra GS. 1977. Estimation of a Production Model with Application to Pastoral one of Eastern Australia.Australian Journal of Agricultural Economics 21: 169-179.

Belon I, Manuel R, Idoi Z. 2003. Assessing the Technical Efficiency of Agricultural Production in Navarra, Spain. Agricultural Systems 78: 387-403.
Ben-Belhassen B. 2002. Measurement and Explanation of Technical Efficiency in Missouri Hog Production. A paper presented at the Annual meeting of American Agricultural Economics Association, Tampa, Florida.

Benjamin MK, Francis JM, Stephen MG, Craig GY, Julia S. 2014. "Assessment of production constraints and farmers' preferences for sweet potato genotypes". J. plant breeds genetics. 02(01): 15-29

Cechura L, Heinrich H, Zdenka M, Michal M. 2014. Productivity and Efficiency Differences Between Czech and Slovak Milk Producers, Review of Agricultural Applied Economics, XVII (2): $17-21$

Coelli T, Rao DSP, Battese GE.1998. Introduction to Efficiency and Production Analysis. Kluwer Academic Publisher, USA.

Coelli T, Rahman S, Thirtle C. 2002. Technical, Allocative cost and scale Efficiencies in Bangladesh Rice Cultivation: A Non Parametric Approach. Journal of Agricultural Economics and Rural Sociology, Ahmadu Bello University, Zaria, Nigeria.

Ekong EE. 2003. An Introduction to Rural Sociology. Dove education publishers, Uyo Nigeria.

Ekwelle MC, Ezulike TO, Eke-Okoro ON. 2001. Contributions of root and tuber crop to the Nigerian economy. In; M. O. Akoroda (ed) Root crops: The small processor and development of local food industry for market economy. Proceedings of the $8^{\text {th }}$ triennial symposium of the International Society for Tropical Root Crops - Africa Branch.

Etim NA, Udoh EJ, Awoyemi TT. 2005. Measuring Technical efficiency of urban farms in Uyo Metropolis. Global Journal of Agricultural Science, 4: 19-95.

Food and Agriculture Organization Statistics (FAOSTAT, 2007), Food and agriculture commodities production: Countries by commodity. Top production of sweet potato2007.http://faostat.foa.org/site/339/default.aspx.

Goni M, Umar ASS, Usman S. 2013. Analysis of Resource-Use Efficiency in Dry Season Vegetable Production in Jere, Borno State, Nigeria. Journal of Biology, Agriculture and Healthcare, 3(19): 18-23.

Horton D. 2008. "Underground Crops. Long Term Trends in Production of Roots and Tubers", Winrock International Institute for Agricultural Development, Arhington, USA https://worldatlas.com/articles/top-sweet-potato-growingcountries.html; retrieved 9/27/2019.

Huntington library Lib. 2006. International Potato Centre: World sweet potato Atlas! Nigeria.jpg!Nigeria//history and origin.www.research.cip.cgiar.org/nigeria.

Irz, X., Lin, L., Thirtle, C., Wiggins, S. 2010 Agricultural Productivity Growth and Poverty Alleviation. Development Policy Review, 19(4): 449-466.

Kay AK, Edwards WM, Duffy PA. 2008. Farm Management. Six edition McGraw Hill Companies Inc

Kerlinger NF. 1973). Foundations of Behavioral Research. New York, Holt Rineheart and Winston Inc.

Meeusen W, Van den Broeck J. 1977. Efficiency Estimation from Cobb-Douglas Production Functions with Composed Error, International Economic Review, 18: 435-444.

Nigerian Root Crop Research Institute (NRCRI). 2000. Sweet Potato Varieties, Nigerian Root Crop Research Institute newsletter.

Njeru J. 2004. Factors influecing technical efficiency in wheat production in Kenya. New Research Proposal Submitted to African Economic Research Consortium, Nairobi, Kenya.

Ogundari K, Ojo SO. 2006. An examination of Technical Economic and Allocation Efficiency of small farms. The case study cassava ferment in Osun state of Nigeria Journal of central European Agriculture 7(3): 430-432.

Ogunyinka EO, Ajibefun IA. 2003. Determinants of Technical Inefficiency on farm productionTobit Analysis Approach to the NDE farmers in Ondo state, Nigeria International Journal of Agriculture and Biology. International Journal of poultry science 2(6): 459-464. 
Ojo SO. 2003. Productivity and Technical Efficiency of Polutry Egg Production in Nigeria. International Journal of Poultry Science 2(6): 459-464

Ojo SO, Ajibefun IA. 2000. Effects of Training on Labour productivity and Efficiency in Oil palm production in Ondo state Nigeria Journal of sustainable Agriculture and Environment 2(64): 275-279

Okonkwo JC, Okoli LSO. 2000. Potato production in Jos plateau; Report of survey of Potato production in four (4) Local Government Areas of Plateau state of Nigeria, NCRI, Vom, Nigeria.

Olarinde LO, Ajao AO, Ajetomba JO. 2005. Socioeconomic characteristics and profitability of contact farmers in Oyo agricultural Zone in a deregulated economy. Journal of Social service 11(3): 177-181.

Onyenweaku CE, Igwe KC, Mbanaso JA. 2004. Application ofstochasticfrontier productionfunction to the measurement of technical efficiency in yam productionin NasarawaState, Nigeria. Journal of SustainableTropicalAgriculture and AgriculturalResearch, 13: 20-25.

Osuala EC. 2005. Introduction to Research Methodology (3rd Edition). Onitsha, Nigeria: African First Publishers Ltd., 307 pp.

Pitt M, Lee L. 1981. The Measurement and Sources of Technical Inefficiency in the IndonesianWeaving Industry, Journal of Development Economics, 9: 43-64.

Rahji MAY. 2005. "Determinant of efficiency differentials in lowland rice productionsystems in Niger State, Nigeria" Ibadan Journal of Agricultural Research1(1): 7-17.
Shrestha RB, Huang W, Pradhan U. 2015. Resource use efficiency in vegetable production in the high hills of Eastern Nepal. Nepalese J. Agri. Econ, 2(3): 79-87.

Tewe OO, Ojeniye FE, Abu OA. 2003. sweet potato production, utilization and marketingin Nigeria. In: Akorodo M.O. and Ngeve J.M., (eds.) Root crops on the twenty-first century. Proceeding of the seventeenth triennial symposium of the international soceity for Tropical Root crops-Africa branch, Cotonou, Benin.

UNCTAD. 2012. Infocomm Commodity Profile Sweet Potato. Sweet potato- UNCTAD.org.,

http//reseach.cip.cgiar.org/influence/display/cipqn/sweetpotato.

Warammboi, J. G., Dennien, S., Gidley, M. J., and Sopade, P. 2011. Characterization of Sweet potato from Papua New Guinea and Australia: Physicochemical, Pasting and Gelatinization Properties. Food Chemistry, 126, 1759-1770. http://dx.doi.org/10.1016 /j.foodchem.2010.12.077

Wilson P, David H, Carol A. 2001.The influence of Management Characteristics on the Technical Efficiency of wheat farmers in Eastern England. Agricultural Economics 24: 329-338. WFP. 1995. World Food Programme, Annual Report.

Woolfe JA. 2002. Sweet Potato: An Untapped Resource". Press Syndicate of Cambridge, UK

World Bank. 2003. "Delivering the Food to Africa, World Food Programme" Journal of world Bank Agricultural Economics. Zuraida N. 2003. Sweet potato as an alternative Food Supplement During Rice Shortage, Journal Litbang Pertanian, 22(4). 